\title{
Retraining scheme could go Europe-wide
}

[MUNICH] An experimental project to retrain unemployed scientists from the former East Germany appears so successful that European Commission officials are now "looking favourably" at backing similar schemes elsewhere in Europe.

The scheme, using European Union (EU) funds, was introduced last year by the Max Delbrück Centre for Molecular Medicine (MDC) in Berlin, where 60 scientists are employed using money from the European Social Fund (ESF), part of the EU's subsidies for poor regions (see Nature 388, 109; 1997).

After only one year of the three-year retraining scheme, more than one in ten have found permanent positions or won independent grant money. A further DM10 million (US\$6 million) was approved earlier this year to retrain 46 researchers at Berlin's Adlershof Science Park. Other institutes in Berlin, Brandenburg and Sachsen-Anhalt have also applied for ESF money.

EU representatives told a meeting in Berlin that the encouraging results mean the scheme may be expanded to other regions after 2000. Cuts in public spending mean that many countries, such as Spain and Portugal, face major difficulties in providing full-time research posts for researchers who have completed their postdoctoral training.

ESF training programmes have traditionally been restricted to unqualified work- ers. But Karl Freese, of the Association of Biomedical Research, a German lobby group representing 15 non-university biomedical research institutes, is one of many campaigning for qualified workers to be included.

Freese argues that scientists educated in the former East Germany, for example, did not have the chance to learn modern scientific techniques. He is worried that several thousand face dismissal when their nonrenewable short-term contracts expire in the autumn. "Unemployment among scientists is a waste of human creativity," says Freese.

The commission appears to have been won round. But Hans Keirat, an EU official who oversees allocation of social funds for east Germany, warns that before other countries can take advantage of it, the commission "wants to be convinced" that the Berlin programmes have really reduced long-term unemployment. Marion Bimmler, of the MDC's personnel department, accepts that the centre needs more time to find out if this goal can be achieved. "But we are very optimistic about it," she says, denying that the scheme is merely a "welfare act".

Participants continue to work in established research groups while retraining in new techniques. According to Bimmler, cooperation between the 'trainees' and staff researchers has been excellent. "ESF-funded scientists have contributed to many publica- tions and patents and have even co-founded new companies," she says.

Karla Köpke, for example, a 47-year-old mathematician, worked for the Academy of Sciences before reunification and then at the Humboldt University in Berlin, until her funding ran out in 1996. Last year she joined a research group at the MDC analysing genes underlying drug addiction. She developed a mathematical method for analysing the polymorphic profiles of candidate genes, which was not possible by conventional methods. "It was because of Köpke's work that we managed to develop a classification of various genetic profiles," says Margarete Hoehe, head of the research group. Köpke's method is to be patented.

If the Berlin results continue to be positive, the chances of creating a general scheme for retraining unemployed scientists are high. Changes in the distribution of EU subsidies to poor regions, which absorb a third of the EU's total budget, are being negotiated. After 2000 they are likely to be used to address general issues such as unemployment throughout the EU.

Biochemist Christof Tannert, a socialist member of the European Parliament from east Germany, says: "Social funds alone cannot solve unemployment among scientists. But the fact that their doors are now open to scientists will help."

QuirinSchiermeier

\section{Stock market crash threatens start-up biotech companies}

[SAN FRANCISCO] The plunge in the US stock market may finally knock biotechnology shares out of the doldrums and trigger more investor interest, experts suggest.

At the same time, they warn that the industry may suffer enough in the short term to propel the weakest, particularly new companies, into mergers or out of business.

In the two weeks up to 4 September US investors suffered their worst episode since the ten days before the stock market crashed in 1987. The Dow Jones Industrial Average plunged 512 points on 31 August, and by the end of the week was down 3.4 per cent for the year. The Nasdaq index, which more closely reflects the performance of technology and biotechnology stocks, dropped 73.16 points over the week, 0.2 per cent down for the year. Another measure, the Russell index of small company stocks, rose slightly, but is down 20.6 per cent for the year.

Biotechnology stocks have been weak since last October, when concerns about the crisis in Asia hit investors' nerves, but stock market analysts saw reason for optimism.

The strong performance of the Dow Industrial Average and the S\&P 500 had taken away the incentive to hold smaller stocks, says Dave Stone, managing director and biotechnology analyst at S. G. Cowen Securities Corp. in Boston. Now investors may be drawn to biotechnology by the industry's improving fundamentals.

"Shaking investors off the bandwagon is probably not a bad thing for the biotech sector," says Stone.

In fact, a few biotech companies bounced back up later last week. These included industry leader Chiron, based in Emeryville, California; Vertex Pharmaceuticals, a specialist in structure-based drug design for viral diseases, in Cambridge, Massachusetts; and AgriBiotech, a Las Vegas forage and turf seed company. Shares in the San Diegobased agricultural biotechnology company Mycogen rose $\$ 5.72$ to $\$ 27.66$ a share. On 1 September, Dow Chemical said it would buy the 32 per cent of Mycogen it did not own for $\$ 28$ a share, or nearly $\$ 325$ million.

James McCamant, editor of the Medical Technology Stock Letter, has urged readers to load up immediately on biotech stocks. Biotechnology companies are barely affected by the worldwide economic swings because they serve the burgeoning US medical sector, he wrote. Wall Street has largely ignored strong sales of new products such as Agouron's AIDS drug Viracept, good clinical trial results, broad-based development programmes and smart corporate deals creating some compelling bargains.

Those bargain prices have made it hard for companies to raise capital for operations, however. Misha Petkevich, managing partner in Petkevich and Partners in San Francisco, predicted increasing difficulty for biotechnology companies not seen as solid in technology and management. Those with a broad technology platform, a product close to market, or involved in a service function such as gene identification may benefit from a period of consolidated investor interest while others fall by the wayside, he said.

Petkevich said the outlook for new biotechnology companies was less encouraging. While venture capitalists have plenty of cash right now, "there's a significant exodus from being involved in start-up biotech companies," he said. Venture capitalists have been lukewarm towards bioscience for the past year, and the recent stock market volatility has not helped to increase their interest. Sally Lehrman 